\section{Famous foreign faces}

AMONG the wave of new companies coming to Tsukuba are several wellknown foreign names, including the giant pharmaceutical and chemical concerns $\mathrm{Glaxo}, \mathrm{ICl}$ and Upjohn, and the US semiconductor manufacturers Intel and Texas Instruments.

Upjohn's huge laboratory with 170 researchers was completed in 1988 at a cost of $¥ 14,000$ million ( $\$ 87$ million). A spokesman says that the decision to a set up in Tsukuba is part of a global strategy to have research centres in the three key markets of the world: the United States, Japan and Europe.

Glaxo gives similar reasons for spending $¥ 20,000$ million on a laboratory that will open in 1992 with a planned staff of 250 researchers.

At present, about 70 per cent of Upjohn's efforts are devoted to the clinical development of drugs for the Japanese market, which is second in size only to that of the United States.

But in the future the institute intends to devote more effort to the development of new drugs for markets throughout the world by "tapping into the rapidly expanding resource of Japanese pharmaceutical science".

Similarly, Texas Instruments intends to expend much of its efforts on basic research when its opens an institute for semiconductor research next year with an initial complement of 100 to 150 researchers drawn mainly from Japan.

D.S.

industrial users, for example, and there are over 80 'research clubs' many of which are centred on Tsukuba University.

In addition, the local Ibaraki prefectural government, the Japan Development Bank, and 74 companies last year established the Tsukuba Research Support Centre, with a fund of $¥ 28,000$ million ( $\$ 175$ million) to provide companies and researchers with information on the latest developments in the science city. But while information networks may be welldeveloped, Tsukuba's transportation system remains grim. The only direct route to Tokyo is by bus which takes just over an hour, provided there are no traffic jams and a seat is available. Local government officials promise a direct train line to Tokyo within the next ten years, and there are also plans to build a highway in a huge loop around Tokyo passing near Tsukuba and joining the ends of the yetto-be-built Tokyo Bay bridge.

If either plan is realized, Tsukuba can expect another surge in development and as one researcher put it "I can sell my house and retire on the proceeds".

Davld Swinbanks

Back to the future

\section{Munich}

IN a bid to encourage the rebirth of culture and science, researchers and professional people have reestablished Romania's Atheneum Society, a scientific academy banned in 1947 by the Communists.

The refounding of the society is important because the Romanian Academy is now discredited. The founders believe that only by starting a new and separate organization can science and culture be restored to their proper place in Romanian society. But vice president Ion Mircea Enescu, an architect, emphasizes that the society is not intended to replace the academy.

The original Atheneum Society was founded in 1865 as a cultural and learned society with 33 sections, from biology, law, fine arts and medicine to architecture and "fundamental science" - physics, mathematics, geometry and philosophy. It will be reconstituted in the same form, with the number of members fixed at 151 .

Significantly, the Culture Ministry in the interim government of Ion Iliescu has offered its support to the society, but the amount is not yet clear. The society hopes to receive support through 'subscriptions' sold in Romania and abroad.
"We want only professionals" for the new society, says Enescu. The society, which has already nominated 100 members, will select only people considered politically "beyond reproach", he says. A very few were in the Communist Party but none were "professionally involved". None of the current academy members have been asked to join.

Another difference is the age of the members. Enescu says that the Atheneum Society will nominate only people who are still active in their fields. The current nominees are between the ages of 45 and 70 . The average age of academy members is over 75 years.

At first, the society will sponsor public lectures and conferences on topics of current relevance such as ecology and the "philosophy of architecture and construction in Romania", says Enescu. The society may also advise the government in some capacity, though "we don't yet know the mechanism for this", he says.

Enescu is hopeful that the society will receive political as well as financial support from the Iliescu government, even though he pronounces the 20 May election that swept Iliescu to the presidency "a fake". AIDS

\title{
One finger in the Romanian dike
}

\section{Munich}

A NEW report from the Romanian government suggests that efforts by it and foreign organizations are failing to stop the spread of AIDS in Romania. The report reveals that there were 478 cases of clinical AIDS in Romania as at 1 May, far more than the earlier estimates of 100 cases.

Even the new figure may be a drastic underestimate of the true situation. It is not known how many people are infected with HIV, the virus that causes AIDS.

Most alarming, 428 of the cases were found in children less than 13 years old. Of these $\mathbf{4 2 4}$ are under four. The now discontinued practice of giving 'microtransfusions' of blood to malnourished infants, many of them orphans, is thought to be behind the explosive spread of AIDS (see Nature 343, 579; 1990).

The blood supply, and the needles and syringes used, were contaminated by the AIDS virus. In a random nationwide sample of blood taken from children in orphanages, nearly ten per cent of the children tested positive for HIV, although the World Health Organization (WHO), based in Geneva, warns that this number might be high because of double reporting.

Testing of blood donors (there are an estimated 600,000 in Romania annually) and of blood already stored in blood banks is not being carried out systematically, partly because of a shortage of testing equipment. Disorganization in the Health Ministry is also to blame.

Foreign relief organizations have delivered modern test equipment as well as thousands of sterile syringes and needles for injections and transfusions. The French organization Medicins du Monde alone has provided three ELISA (enzyme-linked immunosorbent assay) readers and thousands of test kits to laboratories in Bucharest for AIDS testing. But the Health Ministry has begun testing blood only in Bucharest and the three hard-hit eastern cities of Constanta, Iasi and Giurgiu. At least $20-25$ laboratories including readers and kits will be required before blood screening can be comprehensive.

Romania's AIDS troubles may have only begun. Testing blood is a relatively simple job, says epidemiologist David Heymann of WHO, compared to the monumental task of educating the population about AIDS. According to Heymann, the Romanian press is just beginning to tackle the job. The regime of late dictator Nicolae Ceaucescu, which was overthrown in a bloody revolution in December 1989, had always claimed that AIDS did not exist in Romania and even forbade physicians to discuss it publicly.
Steven Dickman 